\title{
Grain Yield in Indirect Selection for Multiple Characters in Upland Rice
}

\author{
Laís M. Tomé ${ }^{1}$, Flávia B. S. Botelho ${ }^{1}$, Douglas G. Castro ${ }^{1}$, Tácio P. da Silva ${ }^{1}$, Camila Soares Cardoso da Silva ${ }^{1}$ \\ $\&$ Amanda Mendes de Moura ${ }^{1}$ \\ ${ }^{1}$ Agricultural Department, Federal University of Lavras, Lavras, Minas Gerais, Brazil \\ Correspondence: Douglas Goulart Castro, Agricultural Department, Federal University of Lavras, Lavras, Minas \\ Gerais, Brazil. Tel: 55-359-9153-8018. E-mail: douglasgoulartcastro@gmail.com
}

Received: October 5, 2018

Accepted: November 6, $2018 \quad$ Online Published: January 15, 2019

doi:10.5539/jas.v11n2p516

URL: https://doi.org/10.5539/jas.v11n2p516

\begin{abstract}
The aim of the present study was to compare the selection performed by the sum of standardized variables index ( $\mathrm{Z}$ Index) with the selection based only on the grain yield character, to verify if the grain yield alone is a good alternative for the selection involving multiple characters. The experiments were conducted in Lavras-MG and in Lambari-MG, during the 2015/2016 agricultural year. The used design was the randomized complete block design with 3 replications. Thirty-six genotypes of the preliminary trial of upland rice breeding program of the Federal University of Lavras were evaluated. In order to compose the $Z$ index, the following characteristics were evaluated: grain yield, height, number of days for flowering, 1000-grain weight, income, yield, leaf blast incidence, and grain length/width ratio. $\mathrm{Z}$ index was efficient in the selection for multiple characters whereas not all lines with the highest grain yield obtained good results in the other desirable characteristics, indicating that the selection based only on grain yield is not efficient when working with several characters of interest in upland rice cultivation.
\end{abstract}

Keywords: Oryza sativa, multiple characters, selection index, selection efficiency

\section{Introduction}

In order to launch an upland rice cultivar, the breeder must associate a number of desirable traits that provide high yield and meet market requirements. Thus, in a breeding program, no attribute can be left out at the time of selection. In addition to grain yield, a good rice cultivar must associate characteristics that facilitate cultural treatments and also provide good industrial and culinary quality. Handling multiple characters at the same time and efficiently is a great challenge and the breeder must always be looking for alternatives that facilitate selection, but at the same time promote the selection of desirable genotypes effectively.

One option is to use the simultaneous selection of the characters involved, through the use of selection indexes, which combine the information of all the characters, so that the selection is based on a single value involving all the others (Ramalho et al., 2012). Several methodologies of selection indexes are found in the literature, among them the sum of standardized variables index ( $\mathrm{Z}$ Index), in this index the character data are standardized to make them directly comparable (Nunes et al., 2005). Good results were obtained in beans (Mendes, 2009; Lima, 2015) and eucalyptus (Reis, 2015) with the use of this method.

In spite of the good results found in literature, the use of the selection indexes in the breeding programs are small and the grain yield character is often the criterion used for the selection of the best genotypes, being the characteristic considered of major importance in most of the breeding programs. However, in the selection of lines to obtain new rice cultivars, the genotype should encompass a series of desirable characteristics, all of which are important for the quality of the final product. Therefore, selection based on one or a few characteristics may be inadequate, leading to a superior material only in relation to the selected characters (Cruz, Regazzi, \& Carneiro, 2012).

Therefore, this paper aimed to compare the selection performed by the $\mathrm{Z}$ index with the selection through the grain yield character, to verify if the grain yield alone is a good alternative for the selection involving multiple characters in upland rice. 


\section{Material and Methods}

\subsection{Study Area Description}

The experiments were conducted in Lavras-MG, Brazil, latitude $21^{\circ} 14^{\prime} \mathrm{S}$, longitude $44^{\circ} 59^{\prime} \mathrm{W}$, altitude $919 \mathrm{~m}$ and climate $\mathrm{Cwa}$, at the Center for scientific and technological development in agriculture of the Federal University of Lavras, and in Lambari-MG, Brazil, latitude $21^{\circ} 58^{\prime} \mathrm{S}$, longitude $45^{\circ} 21^{\prime} \mathrm{W}$, altitude $887 \mathrm{~m}$ and climate Cwa, at the EPAMIG (Agricultural Research Company of Minas Gerais) experimental farm during the 2015/2016 agricultural year.

\subsection{Plant Materials}

A total of 36 upland rice lines with three replications from the preliminary trial of upland rice breeding program of the Federal University of Lavras were evaluated (Table 1). The preliminary trial considers the upland rice elite lines, the selected lines were advanced to final tests, for later selection and launching.

Table 1. Description of the 36 upland rice lines used in the experiments

\begin{tabular}{ll:ll}
\hline Identification & Genotypes & Identification & Genotypes \\
\hline 1 & BRSMG Caravera & 19 & CMG ERF 221-26 \\
2 & BRS Esmeralda & 20 & CMG ERF 221-27 \\
3 & CMG ERF 81-1 & 21 & CMG ERF 221-28 \\
4 & CMG ERF 185-3 & 22 & CMG ERF 221-29 \\
5 & CMG ERF 221-1 & 23 & CMG ERF 221-30 \\
6 & CMG ERF 221-4 & 24 & CMG F6 LAV 1-1 \\
7 & CMG ERF 221-5 & 25 & CMG F6 LAV 1-2 \\
8 & CMG ERF 221-6 & 26 & CMG F6 LAV 1-3 \\
9 & CMG ERF 221-7 & 27 & CMG F6 LAV 8-1 \\
10 & CMG ERF 221-9 & 28 & CMG F6 LAV 8-2 \\
11 & CMG ERF 221-16 & 29 & CMG CMG 116-6 \\
12 & CMG ERF 221-17 & 30 & CMG CMG 116-7 \\
13 & CMG ERF 221-18 & 31 & CMG CMG 822-1 \\
14 & CMG ERF 221-19 & 32 & CMG 419-2 \\
15 & CMG ERF 221-20 & 33 & CMG 2121 \\
16 & CMG ERF 221-21 & 34 & CMG 2143 \\
17 & CMG ERF 221-23 & 35 & CMG 2171 \\
18 & CMG ERF 221-24 & 36 & CMG2071 \\
\hline
\end{tabular}

\subsection{Experimental Conduction}

The used design was the randomized complete block design with 3 replications. Individual and joint variance analyses were performed for all characters using the GENES software system (Cruz, 2001).

The plots consisted of four rows of $5 \mathrm{~m}$, the seeding density was 80 seeds per linear meter with spacing among rows of $35 \mathrm{~cm}$, and a useful plot of $4.8 \mathrm{~m}^{2}$. The cultivation treatments used in the experiments were the same as those recommended for upland rice cultivation, however, without fungicide application, since the evaluation of the diseases incidence was part of the methodology.

\subsection{Characteristics Evaluated}

The following phenotypic characteristics were evaluated: Plant height: from ground level to the end of the panicle of the main stem (five plants per plot randomly chosen); Incidence of leaf blast: the scale recommended by the International Rice Research Institute (IRRI, 1996) was used, where, score 0: no incidence; score 1: less than $5 \%$ of infected panicles; score 3: from $5 \%$ to $10 \%$ of infected panicles; score 5 : between $11 \%$ and $25 \%$ of infected panicles; score 7: between $26 \%$ and $50 \%$ of infected panicles, and score 9: greater than $50 \%$ of infected panicles. Number of days for flowering: number of days after planting up to $50 \%$ of plants from the plot emitted panicles; Grain yield: in grams per plot adjusted for kg ha, referring to the plot useful area (two central lines); 100 grain weight: weight of 100 grains, repeated eight times, being the obtained average multiplied by 10 , according to the rules for seed analysis; Income: percentage of processed (clean) rice resulting from the 
processing of paddy rice; Yield: percentage of whole grains resulting from the process of rice grains; Length/width ratio: measured by the GroundEye seed analysis system, average of 100 grains per plot.

\subsubsection{Sum of Standardized Variables $(Z)$}

Eight characters under study were considered and a selection intensity of $10 \%$ was assigned on the lines for the evaluated characters, totaling four selected lines.

Character data were standardized per plot using the following estimator:

$$
\mathrm{Z}_{\mathrm{ijq}}=\mathrm{Y}_{\mathrm{ijq}}-\mathrm{Y}_{\mathrm{qj}} / \mathrm{S}_{\mathrm{qj}}
$$

where,

$Y_{\mathrm{ijq}}$ : is the observation of the progeny $\mathrm{i}$ in the repetition $\mathrm{j}$ for the character $\mathrm{q} ; \mathrm{Y}_{\mathrm{qj}}$ : is the general average of the character $\mathrm{q}$ in the replication $\mathrm{j} ; \mathrm{S}_{\mathrm{qj}}$ : is the phenotypic standard deviation of the character $\mathrm{q}$ in the replication $\mathrm{j}$.

As the variable $Z_{\mathrm{ijq}}$ assumes positive and negative values, the value four was added to the estimates in order to avoid negative values. Therefore, the population average became four, instead of zero. After obtaining the values for the eight characteristics, the sum of the $Z$ index was performed. The index $(Z)$ was performed using the Excel software system (2007). For the construction of the plot, the GGE-Biplot (Genotype and Genotype-Environment Interaction) method was used by the model (Yan et al., 2001), using software R (2015).

\section{Results}

It was observed that the coefficient of variation was below $20 \%$ for almost all evaluated characters, indicating a good experimental precision, except for leaf blast, in which the character presented a moderate experimental precision (Table 2).

This can be justified because disease evaluations are performed by indirect method. Evaluations about the distribution of the $\mathrm{CV} \%$ in experiments with upland rice related to diseases usually have high coefficients of variation (Costa, 2002).

The analysis of joint variance was performed and the $F$ test $(p<0.05)$ was significant for grain yield and the other characters used to compose the $\mathrm{Z}$ index. The $\mathrm{Z}$ index also has the advantage of allowing the analysis of variance, since it is estimated by plot, and a significant difference was also detected by the $F$ test $(p<0.05)$.

Table 2 also shows the averages of the $Z$ index and the other evaluated characters. The lines were grouped in distinct phenotypic classes by the Scott and Knott test $(p<0.05)$ for all the characters and also by the $Z$ index, indicating that there is variance among the lines in relation to all evaluated characteristics, being possible to select superior lines for the desirable characters, an essential fact for the success of the breeding program. 
Table 2. Averages of Z-index and the characteristics grain yield (GY), number of days for flowering, height 1000-grain weight (weight), income, yield, length/width ratio (L/W) and leaf blast (LB)

\begin{tabular}{|c|c|c|c|c|c|c|c|c|c|}
\hline Genotypes & $\mathrm{Z}$ & GY & Height & Flower $^{1}$ & Weight $^{1}$ & Income & Yield & $\mathrm{L} / \mathrm{W}^{1}$ & $\mathrm{LB}^{1}$ \\
\hline & index & $\mathrm{kg} / \mathrm{ha}$ & $\mathrm{cm}$ & days & --------- & --- g ---- & - & $\mathrm{cm}$ & notas \\
\hline 1 & $28.77 \mathrm{a}$ & $4646.8 \mathrm{~b}$ & $102 \mathrm{a}$ & $77 \mathrm{a}$ & $27.6 \mathrm{a}$ & $70.04 \mathrm{~b}$ & $41.3 \mathrm{~b}$ & $3.39 \mathrm{~b}$ & $2.8 \mathrm{a}$ \\
\hline 2 & $24.82 \mathrm{~b}$ & $4306.7 \mathrm{~b}$ & $111 \mathrm{~b}$ & $86 \mathrm{c}$ & $23.6 \mathrm{~b}$ & $69.27 \mathrm{~b}$ & $40.5 \mathrm{~b}$ & $3.35 \mathrm{~b}$ & $4.0 \mathrm{~b}$ \\
\hline 3 & $28.15 \mathrm{a}$ & $4624.2 \mathrm{~b}$ & $112 \mathrm{~b}$ & $77 \mathrm{a}$ & $26.7 \mathrm{a}$ & $72.01 \mathrm{a}$ & $44.9 \mathrm{a}$ & $3.12 \mathrm{~b}$ & $3.6 \mathrm{~b}$ \\
\hline 4 & $27.16 \mathrm{a}$ & $4156.3 \mathrm{~b}$ & $109 \mathrm{~b}$ & $82 \mathrm{~b}$ & $25.4 \mathrm{~b}$ & $71.72 \mathrm{a}$ & $39.5 \mathrm{~b}$ & $3.36 \mathrm{~b}$ & $3.8 \mathrm{~b}$ \\
\hline 5 & $28.23 \mathrm{a}$ & $4841.7 \mathrm{a}$ & $100 \mathrm{a}$ & $83 \mathrm{~b}$ & $28.2 \mathrm{a}$ & $71.13 \mathrm{a}$ & $38.6 \mathrm{~b}$ & $3.59 \mathrm{a}$ & $4.9 \mathrm{~b}$ \\
\hline 6 & $28.07 \mathrm{a}$ & $5046.0 \mathrm{a}$ & $100 \mathrm{a}$ & $83 \mathrm{~b}$ & $29.7 \mathrm{a}$ & $70.43 \mathrm{a}$ & $36.9 \mathrm{~b}$ & $3.58 \mathrm{a}$ & $4.0 \mathrm{~b}$ \\
\hline 7 & $28.52 \mathrm{a}$ & $4547.2 \mathrm{~b}$ & $100 \mathrm{a}$ & $85 \mathrm{~b}$ & $29.2 \mathrm{a}$ & $70.68 \mathrm{a}$ & $38.0 \mathrm{~b}$ & $3.67 \mathrm{a}$ & $3.5 \mathrm{~b}$ \\
\hline 8 & $27.18 \mathrm{a}$ & $4330.6 \mathrm{~b}$ & $103 \mathrm{a}$ & $80 \mathrm{a}$ & $25.9 \mathrm{~b}$ & $70.37 \mathrm{a}$ & $46.4 \mathrm{a}$ & $3.31 \mathrm{~b}$ & $3.8 \mathrm{~b}$ \\
\hline 9 & $27.65 \mathrm{a}$ & $4942.5 \mathrm{a}$ & $100 \mathrm{a}$ & $84 \mathrm{~b}$ & $26.4 \mathrm{a}$ & $69.95 \mathrm{~b}$ & $36.2 \mathrm{~b}$ & $3.78 \mathrm{a}$ & $3.8 \mathrm{~b}$ \\
\hline 10 & $29.54 \mathrm{a}$ & $5233.3 \mathrm{a}$ & $104 \mathrm{a}$ & $81 \mathrm{a}$ & $28.7 \mathrm{a}$ & $71.09 \mathrm{a}$ & $39.4 \mathrm{~b}$ & $3.57 \mathrm{a}$ & $3.3 \mathrm{~b}$ \\
\hline 11 & $28.67 \mathrm{a}$ & $5191.7 \mathrm{a}$ & $106 \mathrm{~b}$ & $83 \mathrm{~b}$ & $28.5 \mathrm{a}$ & $70.56 \mathrm{a}$ & $34.9 \mathrm{~b}$ & $3.60 \mathrm{a}$ & $3.8 \mathrm{~b}$ \\
\hline 12 & $27.66 \mathrm{a}$ & $4924.6 \mathrm{a}$ & $105 \mathrm{a}$ & $84 \mathrm{~b}$ & $26.7 \mathrm{a}$ & $69.76 \mathrm{~b}$ & $43.3 \mathrm{a}$ & $3.64 \mathrm{a}$ & $2.4 \mathrm{~b}$ \\
\hline 13 & 29.88 a & $5091.7 \mathrm{a}$ & $105 \mathrm{a}$ & $82 \mathrm{~b}$ & $27.1 \mathrm{a}$ & $71.40 \mathrm{a}$ & $38.8 \mathrm{~b}$ & $3.54 \mathrm{a}$ & $2.2 \mathrm{a}$ \\
\hline 14 & $30.16 \mathrm{a}$ & $5379.0 \mathrm{a}$ & $104 \mathrm{a}$ & $83 \mathrm{~b}$ & $29.5 \mathrm{a}$ & $71.56 \mathrm{a}$ & $40.6 \mathrm{~b}$ & $3.49 \mathrm{a}$ & $3.0 \mathrm{a}$ \\
\hline 15 & $28.45 \mathrm{a}$ & $5070.2 \mathrm{a}$ & $101 \mathrm{a}$ & $85 \mathrm{~b}$ & $27.0 \mathrm{a}$ & $70.65 \mathrm{a}$ & $43.6 \mathrm{a}$ & $3.51 \mathrm{a}$ & $3.1 \mathrm{~b}$ \\
\hline 16 & $25.99 \mathrm{~b}$ & $4396.0 \mathrm{~b}$ & $101 \mathrm{a}$ & $78 \mathrm{a}$ & $26.9 \mathrm{a}$ & $68.08 \mathrm{c}$ & $34.7 \mathrm{~b}$ & $3.28 \mathrm{~b}$ & $2.6 \mathrm{a}$ \\
\hline 17 & $29.64 \mathrm{a}$ & $4916.3 \mathrm{a}$ & $96 \mathrm{a}$ & $84 \mathrm{~b}$ & $28.5 \mathrm{a}$ & $70.81 \mathrm{a}$ & $38.3 \mathrm{~b}$ & $3.58 \mathrm{a}$ & $2.1 \mathrm{a}$ \\
\hline 18 & $28.74 \mathrm{a}$ & $4821.8 \mathrm{a}$ & $108 \mathrm{~b}$ & $83 \mathrm{~b}$ & $27.3 \mathrm{a}$ & $71.51 \mathrm{a}$ & $37.4 \mathrm{~b}$ & $3.35 \mathrm{~b}$ & $2.8 \mathrm{a}$ \\
\hline 19 & $30.01 \mathrm{a}$ & $4773.8 \mathrm{a}$ & $99 \mathrm{a}$ & $79 \mathrm{a}$ & $28.5 \mathrm{a}$ & $70.60 \mathrm{a}$ & $40.8 \mathrm{~b}$ & $3.45 \mathrm{a}$ & $2.3 \mathrm{a}$ \\
\hline 20 & $29.37 \mathrm{a}$ & $4386.5 \mathrm{~b}$ & $100 \mathrm{a}$ & $83 \mathrm{~b}$ & $27.8 \mathrm{a}$ & $70.76 \mathrm{a}$ & $41.0 \mathrm{~b}$ & $3.59 \mathrm{a}$ & $2.4 \mathrm{a}$ \\
\hline 21 & $27.73 \mathrm{a}$ & $4525.8 \mathrm{~b}$ & $100 \mathrm{a}$ & $82 \mathrm{~b}$ & $27.2 \mathrm{a}$ & $70.75 \mathrm{a}$ & $37.3 \mathrm{~b}$ & $3.42 \mathrm{a}$ & $3.7 \mathrm{~b}$ \\
\hline 22 & $29.41 \mathrm{a}$ & $5105.2 \mathrm{a}$ & $103 \mathrm{a}$ & $82 \mathrm{~b}$ & $27.8 \mathrm{a}$ & $71.07 \mathrm{a}$ & $39.0 \mathrm{~b}$ & $3.68 \mathrm{a}$ & $1.6 \mathrm{a}$ \\
\hline 23 & $29.60 \mathrm{a}$ & $5225.8 \mathrm{a}$ & $108 \mathrm{~b}$ & $82 \mathrm{~b}$ & $25.0 \mathrm{~b}$ & $71.24 \mathrm{a}$ & $41.9 \mathrm{a}$ & $3.43 \mathrm{a}$ & $2.2 \mathrm{a}$ \\
\hline 24 & $28.08 \mathrm{a}$ & $4475.8 \mathrm{~b}$ & $112 \mathrm{~b}$ & $78 \mathrm{a}$ & $25.4 \mathrm{~b}$ & $71.51 \mathrm{a}$ & $40.2 \mathrm{~b}$ & $3.07 \mathrm{~b}$ & $2.4 \mathrm{a}$ \\
\hline 25 & $27.00 \mathrm{a}$ & $4332.5 \mathrm{~b}$ & $114 \mathrm{~b}$ & $80 \mathrm{a}$ & $25.3 \mathrm{~b}$ & $71.40 \mathrm{a}$ & $43.3 \mathrm{a}$ & $3.09 \mathrm{~b}$ & $3.8 \mathrm{~b}$ \\
\hline 26 & $28.09 \mathrm{a}$ & $5186.9 \mathrm{a}$ & $106 \mathrm{~b}$ & $78 \mathrm{a}$ & $25.4 \mathrm{~b}$ & $71.44 \mathrm{a}$ & $42.9 \mathrm{a}$ & $3.26 \mathrm{~b}$ & $3.5 \mathrm{~b}$ \\
\hline 27 & $28.44 \mathrm{a}$ & $3842.5 \mathrm{~b}$ & $97 \mathrm{a}$ & $78 \mathrm{a}$ & $29.1 \mathrm{a}$ & $70.48 \mathrm{a}$ & $32.0 \mathrm{~b}$ & $3.50 \mathrm{a}$ & $2.8 \mathrm{a}$ \\
\hline 28 & $28.37 \mathrm{a}$ & $4245.2 \mathrm{~b}$ & $104 \mathrm{a}$ & $80 \mathrm{~b}$ & $28.3 \mathrm{a}$ & $70.93 \mathrm{a}$ & $45.2 \mathrm{a}$ & $3.18 \mathrm{~b}$ & $3.0 \mathrm{a}$ \\
\hline 29 & $27.71 \mathrm{a}$ & $3812.7 \mathrm{~b}$ & $99 \mathrm{a}$ & $89 \mathrm{c}$ & $24.0 \mathrm{~b}$ & $71.51 \mathrm{a}$ & $48.2 \mathrm{a}$ & $3.11 \mathrm{~b}$ & $2.8 \mathrm{a}$ \\
\hline 30 & $27.00 \mathrm{a}$ & $4108.3 \mathrm{~b}$ & $102 \mathrm{a}$ & $89 c$ & $24.1 \mathrm{~b}$ & $72.13 \mathrm{a}$ & $52.8 \mathrm{a}$ & $3.15 \mathrm{~b}$ & $2.8 \mathrm{a}$ \\
\hline 31 & $25.08 \mathrm{~b}$ & $3754.4 \mathrm{~b}$ & $104 \mathrm{a}$ & $85 \mathrm{~b}$ & $23.0 \mathrm{~b}$ & $69.78 \mathrm{~b}$ & $44.4 \mathrm{a}$ & $3.51 \mathrm{a}$ & $3.3 \mathrm{~b}$ \\
\hline 32 & $24.21 \mathrm{~b}$ & $4268.7 \mathrm{~b}$ & $107 \mathrm{~b}$ & $84 \mathrm{~b}$ & $23.6 \mathrm{~b}$ & $68.48 \mathrm{c}$ & $45.4 \mathrm{a}$ & $3.23 \mathrm{~b}$ & $3.7 \mathrm{~b}$ \\
\hline 33 & $25.29 \mathrm{~b}$ & $4165.1 \mathrm{~b}$ & $101 \mathrm{a}$ & $85 \mathrm{~b}$ & $24.4 \mathrm{~b}$ & $70.80 \mathrm{a}$ & $41.8 \mathrm{a}$ & $3.11 \mathrm{~b}$ & $3.2 \mathrm{~b}$ \\
\hline 34 & $27.68 \mathrm{a}$ & $4375.0 \mathrm{~b}$ & $105 \mathrm{a}$ & $84 \mathrm{~b}$ & $25.0 \mathrm{~b}$ & $71.73 \mathrm{a}$ & $45.2 \mathrm{a}$ & $3.22 \mathrm{~b}$ & $2.5 \mathrm{a}$ \\
\hline 35 & $28.02 \mathrm{a}$ & $5181.3 \mathrm{a}$ & $108 \mathrm{~b}$ & $82 \mathrm{~b}$ & $24.8 \mathrm{~b}$ & $71.50 \mathrm{a}$ & $40.9 \mathrm{~b}$ & $3.28 \mathrm{~b}$ & $2.7 \mathrm{a}$ \\
\hline 36 & $28.98 \mathrm{a}$ & $4781.3 \mathrm{~b}$ & $112 \mathrm{~b}$ & $80 \mathrm{a}$ & $27.2 \mathrm{a}$ & $71.96 \mathrm{a}$ & $36.7 \mathrm{~b}$ & $3.59 \mathrm{a}$ & $1.5 \mathrm{a}$ \\
\hline Average & 29.12 & 4639.26 & 104.02 & 82.06 & 26.63 & 70.8 & 40.89 & 3.4 & 3.2 \\
\hline CV (\%) & 7.63 & 14.00 & 7.24 & 3.49 & 7.77 & 1.89 & 17.65 & 6.49 & 28.94 \\
\hline
\end{tabular}

Note. Averages followed by the same letter belong to the same group by the Scott and Knott test $(\mathrm{p}<0.05) .{ }^{1}$ Flower: Number of days for flowering; Weight: 1000 grain weight; L/W: Length divide by width; LB: Leaf blast; GY: Grain yield.

In order to improve the visualization of the superior genotypes for each case, grain yield and $\mathrm{Z}$ index, it was used the GGEbiplot method (Yan, 2001) in which the graphic analysis helps to visualize important aspects that help the selection, among them, the ranking of the genotypes according to their proximity to an ideotype, as well as in the verification of the best genotypes. 
Figure 1 shows the biplots "discrimination and representativeness". The performance of the genotype is observed with respect to the $\mathrm{x}$ axis, where the more to the right of the center of the biplot the higher the performance and the lower the left the smaller performance. Genotypes located to the left and right of the center of the biplot show inferior performance and superior to the general average, respectively (Silva \& Benin, 2012).
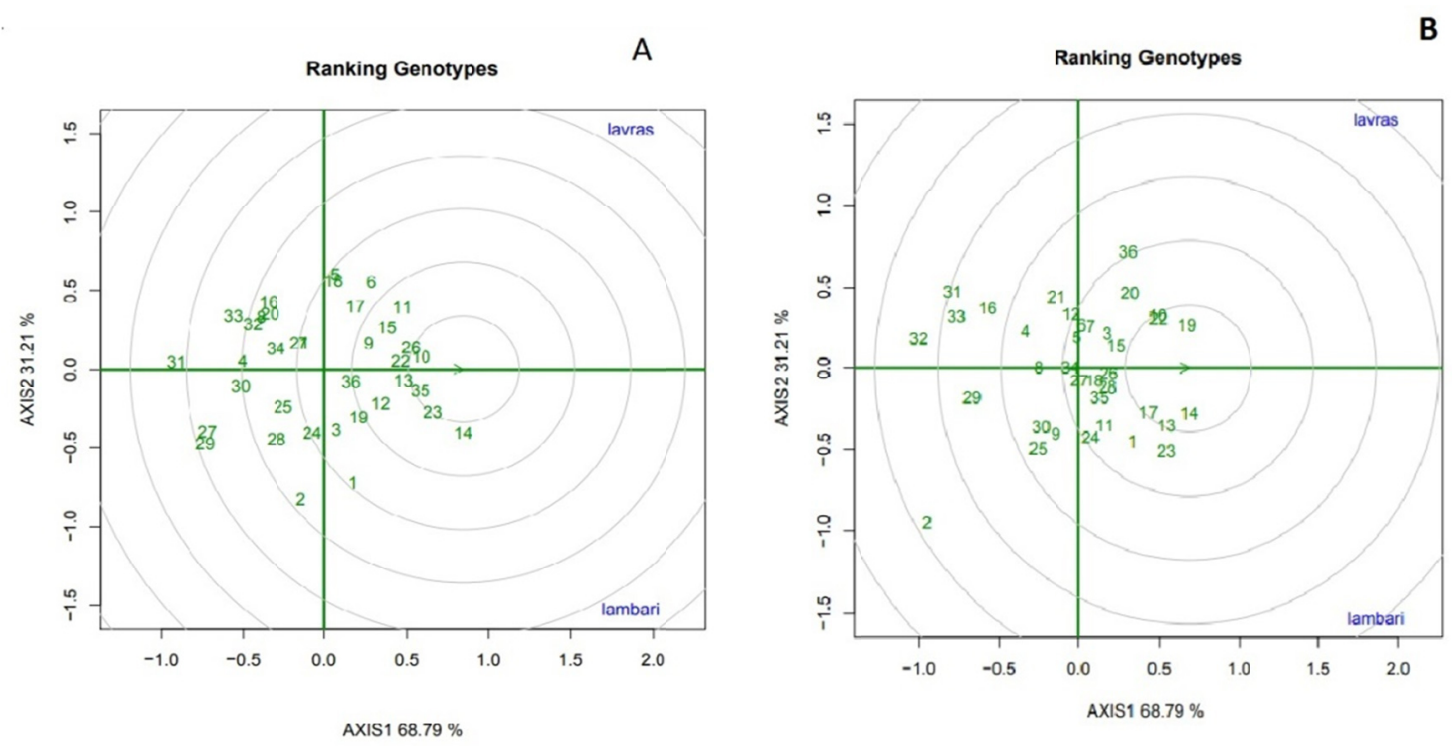

Figure 1. GGE biplot “discrimination and representativeness" A: Grain yield. B: Z Index

\section{Discussion}

Regarding grain yield. the average of the lines was $4639.26 \mathrm{~kg} / \mathrm{ha}$, which is a positive result, since the upland rice grain yield average in Brazil is $2347 \mathrm{~kg} / \mathrm{ha}$ (CONAB, 2017). It can be observed in Table 2 that several lines were superior to the controls (Lines 1 and 2), demonstrating that several genotypes of the program stand out in relation to the character.

It is also noticed that there are lines with better values obtained in the index $\mathrm{Z}$, which indicates that there are also superior lines in relation to all the characters evaluated and desirable for the selection.

In Figure. biplot A, we observed that the lines closest to the center of the circle are the ones closest to the ideal genotype, that is, superior to the grain yield characteristic. It can be observed in the plot that the lines $14,23,35$, $10,13,22$ and 26 obtained the best performance in this case. In biplot B, based on the Z index, the 14 and 19 lines are within the center of the circle, being the ones closest to the ideal genotype, which indicates that these lines were superior for all the characteristics included in the index, followed by the lines 17, 13, 10 and 22 that also performed well in relation to $\mathrm{Z}$ index.

The behavior of the genotypes does not coincide in both biplots, it is observed that the lines 14, 10,13 and 22 are in good position in the grain yield and $\mathrm{Z}$ index plot, but the other lines did not obtain good performance in both biplots. Lines such as 23,26 and 35 were superiors in relation to grain yield, but were not superior in relation to the $\mathrm{Z}$ index, indicating that despite having a high grain yield, they did not perform satisfactorily in one or more of the other evaluated characters.

Oliveira (2014), in his work with selection indexes with corn concluded that grain yield should not be considered as a selection index, because not all of the most grain yield genotypes were the best in the other characters used in the evaluation. Santos et al. (2018) observed that indirect selections among genotype averages are not efficient to provide the desirable responses to the whole set of traits in their work with alfafa.

Regarding the Z-index, Reis et al. (2015) suggest that this index is a reliable option for Eucalyptus breeders. Lima et al. (2015) considered that Z-index is efficient in identifying beans populations that allow superior progenies to be obtained and it was easy to identify in which traits each population showed higher or lower performance than the mean value. $\mathrm{Z}$ index was also useful in common bean breeding programs for biofortification, identifying lines with the highest minerals concentration in the grains (Ribeiro et al., 2013). 
Although several studies addressing selection index in diverse species are found (Rezende et al., 2014; Vivas et al., 2013; Luz et al., 2018), there were not verified more studies regarding Z-index, which can be explained by the fact that it is a more recent selection index. However, good results are observed on studies where Z-index is used.

Besides the ease of obtaining the index, the $\mathrm{Z}$ index also has the advantage of allowing the graphical analysis of the performance of each line. The graphical representation facilitates the visualization for the breeder to identify in which characters a certain line is superior or inferior. Figure 2 shows the plots of the 4 best lines selected using the $\mathrm{Z}$ index. It can be observed that all the characters are close to the average or they are higher than the average, indicating that the selection was favorable for all desirable characteristics. Figure 3 shows the plots of the 4 best lines selected by selection based on the grain yield character and it is noted that with the exception of genotype 14, which was also selected by $\mathrm{Z}$ index, that the other genotypes obtained below average results for some characteristics. Indicating that when selection is targeted to multiple characters selection based only on grain yield is not efficient.

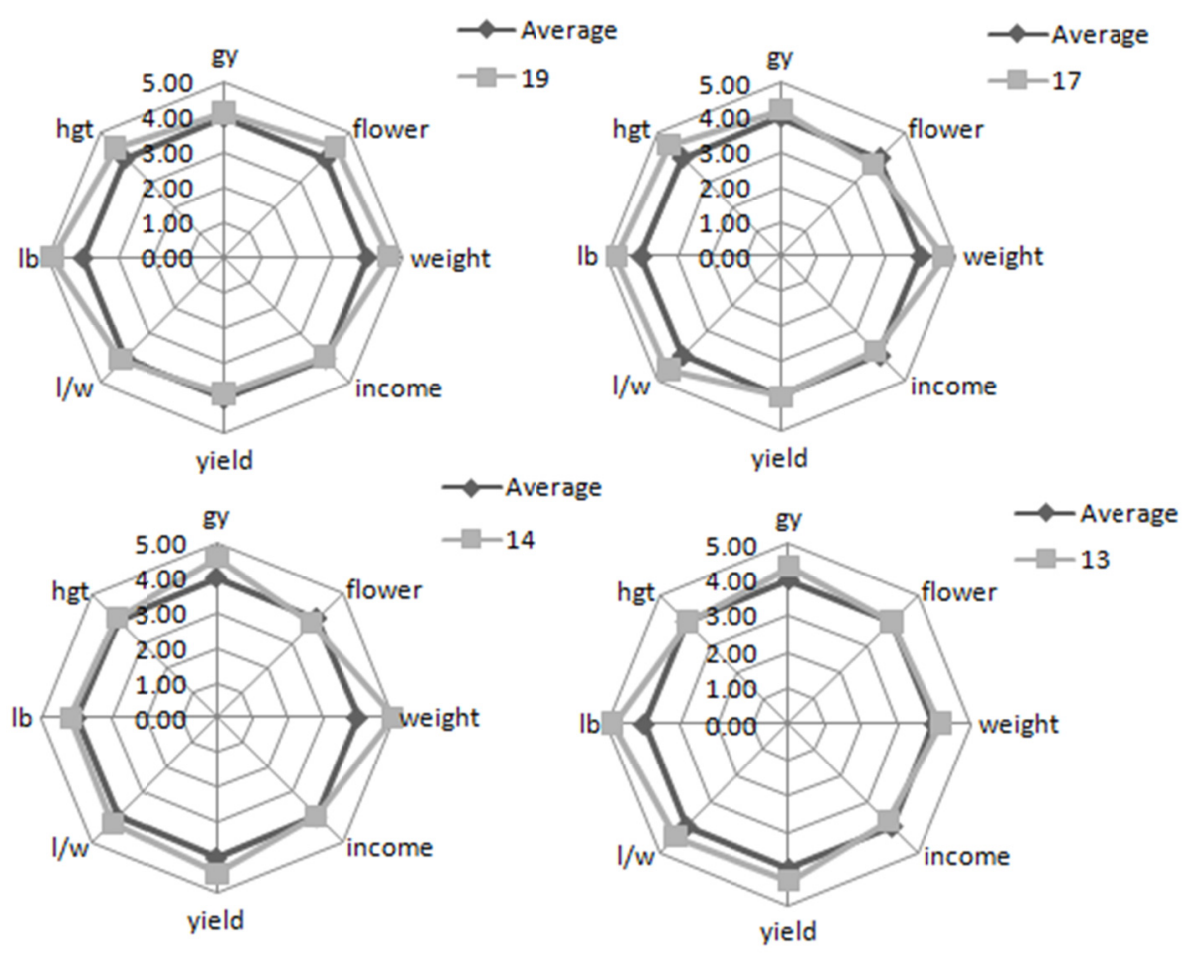

Figure 2. Graphical representation of the standard values of characteristics estimated by $\mathrm{Z}$ index: grain yield (gy), number of days for flowering (flower), 1000-grain weight (weight), income (income), yield (yield), length/width ratio $(\mathrm{l} / \mathrm{w})$, leaf blast $(\mathrm{lb})$ and height (hgt) of the four best lines selected using the $\mathrm{Z}$ index $(14,19,17,13)$ 


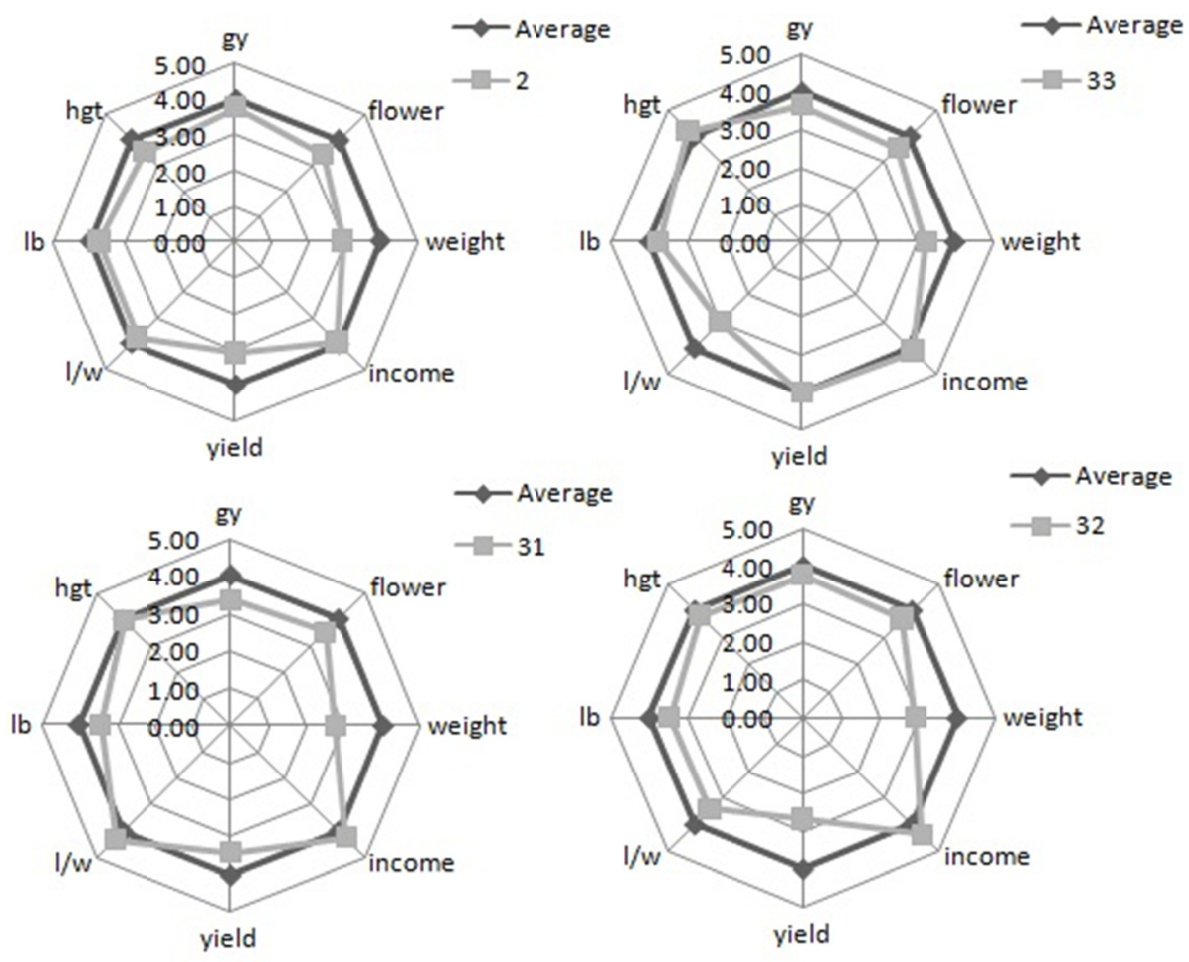

Figure 3. Graphical representation of the standard values of characteristics estimated by $Z$ index: grain yield (gy), number of days for flowering (flower), 1000-grain weight (weight), income (income), yield (yield), length/width ratio $(1 / \mathrm{w})$, leaf blast (lb) and height (hgt) of the 4 best lines selected by selection based on the grain yield $(14,10,23,35)$

\section{Conclusions}

Selection based on the grain yield character alone is not efficient when working with several characters of interest in upland rice cultivation, being necessary the evaluation of the other characteristics for the selection. The use of the Z-index is a reliable alternative for multiple character selection in upland rice.

\section{Acknowledgements}

The authors thank the Fundação de Apoio a Pesquisa de Minas Gerais (FAPEMIG), the Coordenação de Aperfeiçoamento de Pessoal de Nível Superior (CAPES), and The Conselho Nacional de Desenvolvimento Científico e Tecnológico (CNPq), for financial support and scholarships.

\section{References}

CONAB. (2017). Acompanhamento da Safra Brasileira de Grãos 2016/17-Quarto Levantamento (p. 154). Janeiro. http://www.conab.gov.br/OlalaCMS/uploads/arquivos/16_01_12_09_00_46_boletim_graos_janeiro _2017.pdf

Cruz, C. D. (2001). Programa Genes: Versão Windows; Aplicativo computacional em genética e estatística. Editora UFV: Imprensa Universitária, Viçosa.

Cruz, C. D., Regazzi. A. J., \& Carneiro, P. C. S. (2012). Modelos biométricos aplicados ao melhoramento genético (4th ed.). UFV, Viçosa.

Costa, N. H. A. D., Seraphin, J. C., \& Zimmermann, F. J. P. (2002). Novo método de classificação de coeficientes de variação para a cultura do arroz de terras altas. Pesquisa Agropecuária Brasileira, 37, 243-249. https://doi.org/10.1590/S0100-204X2002000300003

IRRI (International Rice Research Institute). (1996). Standard Evaluation Systen for Rice. Manila.

Lima, D. C., Abreu, Â. F. B., Ferreira, R. A. D. C., \& Ramalho, M. A. P. (2015). Breeding common bean populations for traits using selection index. Scientia Agricola, 72, 132-137. https://doi.org/10.1590/0103-90 16-2014-0130 
Luz, P. B. S, Alessandro, A. B., Ambrosio, V C., Neves, L. G., \& Tavares, A. R. (2018). Selection of indexes to evaluate the genetic variability aiming ornamental use of peppers accessions. Ornamental Horticulture, 24(1), 7-11. https://doi.org/10.14295/oh.v24i1.1109

Mendes, F. F., Ramalho, M. A. P., \& Abreu, A. F. B. (2009). Índice de seleção para escolha de populações segregantes de feijoeiro-comum. Pesquisa Agropecuária Brasileira, 44, 1312-1318. https://doi.org/10.1590/ S0100-204X2009001000015

Nunes, J. A. R., Ramalho, M. A. P., \& Abreu, A. F. B. (2005). Graphical method in studies of adaptability and stability of cultivars. Annual Report of the Bean Improvement Cooperative, 48, 182-183.

Oliveira, R. L., Von Pinho, R. G., Ferreira, D. F., Pires, L. P. M., \& Melo, W. M. C. (2014). Selection index in the study of adaptability and stability in maize. The Scientific World Journal, 1-6. https://doi.org/10.1155/ $2014 / 837151$

Ramalho, M. A. P., Abreu, A. F. B., Santos, J. B., \& Nunes, J. A. R. (2012). Aplicações da genética quantitativa no melhoramento de plantas autógamas. Editora UFLA, Lavras.

Reis, C. A. F., Gonçalves, F. M. A., Ramalho, M. P. A., \& Rosado, A. M. (2015). Estratégias na seleção de simultânea de vários caracteres no melhoramento de eucalyptus. Ciência Florestal, 25, 457-467. https://doi.org/10.5902/1980509818465

Rezende, J. C., Botelho, C. E., Oliveira, A. C. B., Silva, F. L., Carvalho, G. R., \& Pereira, A. A. (2014). Genetic progress in coffee progenies by different selection criteria. Coffee Science, 9, 347-353.

Ribeiro, N. D., Mambrin, R. B., Storck, L., Prigol, M., \& Nogueira, C. W. (2013). Combined selection for grain yield, cooking quality and minerals in the common bean. Rev Cienc Agron, 44, 869-877. https://doi.org/ $10.1590 / \mathrm{S} 1806-66902013000400025$

Santos, I. G. dos, Cruz, C. D., scimento, M., Rosado, R. D. S., \& Ferreira, R. de P. (2018). Direct, indirect and simultaneous selection as strategies for alfalfa breeding on forage yield and nutritive value. Pesq. Agropec. Trop., 48(2), 178-189. https://doi.org/10.1590/1983-40632018v4851950

Silva, R. R., \& Benin, G. (2012). Análises Biplot: Conceitos, interpretações e aplicações. Ciência Rural, Santa Maria, 42(8), 1404-1412. https://doi.org/10.1590/S0103-84782012000800012

Vivas, M., Silveira, S. F., Vivas, J. M. F., \& Pereira, M. G. (2013). Predição de ganhos genéticos e seleção de progênies de mamoeiro para resistência à pinta-preta. Trop Plant Pathol, 38, 142-148. https://doi.org/ $10.1590 / \mathrm{S} 1982-56762013000200008$

Yan, W., Cornelius, P. L., Crossa, J., \& Hunt, L. A. (2001). Two types of GGE biplots for analyzing multi environment trial data. Crop Science, 41(3), 656-663. https://doi.org/10.2135/cropsci2001.413656x

\section{Copyrights}

Copyright for this article is retained by the author(s), with first publication rights granted to the journal.

This is an open-access article distributed under the terms and conditions of the Creative Commons Attribution license (http://creativecommons.org/licenses/by/4.0/). 